\title{
Comparative Study of Enzyme Activities Degrading Sorbitol, Ribitol, Xylitol and Gluconate in Guinea Pig Tissues
}

\author{
H. Birnesser, H. Reinauer and S. Hollmann \\ Institute of Physiological Chemistry and Diabetes Research Institute at the University of Düsseldorf, Germany (F.R. G.)
}

Received: July 1, 1972, accepted: October 19, 1972

\begin{abstract}
Summary. In guinea pig tissues the activities of the enzymes D-gluconokinase, sorbitol dehydrogenase, Dribulo- and D-xylulokinase were measured. D-ribulose and $\mathrm{D}$-xylulose were prepared by isomerisation of D-ribose and D-xylose in pyridine and separated by preparative paper chromatography. The activity patterns of the pentulokinases were identical in all tested organs. The highest activities of these two enzymes were found in adipose tissue, when referred to soluble cell protein, and was higher than the activity in liver and kidney. The high enzyme activities of the pentulokinases in adipose tissuo may explain the antilipolytic effect of these pentitols and
\end{abstract}

pentoses in diabetes. The activities of sorbitol dehydrogenase and gluconokinase showed a similar activity pattern in all tested organs of the guinea pig. The highest activities were found in liver and kidney and the lowest in the adipose tissue. The direct metabolism of gluconate in adipose tissue seoms impossible. The activity of the pentulokinases are diminished in the tissues of the diabetic rat.

Key words: Activity of pentulokinases, sorbitol dehydrogenase and gluconokinase-organs of guinea pigs and of normal and diabetic rats.

\section{Introduction}

Pentoses and pentitols, which are metabolised without insulin by the pentose phosphate cycle and glucuronic acid pathway, had an important position in the dietetic treatment of diabetes mellitus. In the diabetes diet these pentoses and pentitols were used as "exchange carbohydrates". The "exchange carbohy. drates" have diminished in importance in the dietetic treatment of diabetes mellitus because of their calorycontent. Nevertheless, the special metabolism of these compounds, which have been shown to have an antilipolytic and antiketogenic effect, has clinical and biological importance.

The aim of the following paper concerns the activity pattern of the enzymes which catalyse the first steps in the degradation of xylitol, ribitol, D-ribulose, D-gluconic acid and sorbitol. Therefore, the activities of the following kinases and of a dehydrogenase have been determined in different organs of guinea pigs and rats: ATP: D-xylulose 5-phosphotransferase (EC 2.7. 1.17) $=\mathrm{D}$-xylulokinase, ATP: D-ribulose 5-phosphotransferase (EC 2.7.1.47) = D-ribulokinase, ATP: Dgluconate 6-phosphotransferase (EC 2.7.1.12) $=\mathrm{D}$. gluconokinase, L-iditol: NAD oxidoreductase (EC 1.1. 1.14) = sorbitol dehydrogenase.

\section{Method}

\section{Reagents}

a) From Boehringer, Mannheim: adenosine-5-triphosphate, sodium salt, nicotinamide-sdenine-dinucleotidophosphate, sodium salt, reduced nicotinamide-adeninedinucleotide, sodium salt, 6-phosphogluconate-dehydrogenase from baker's yeast.

b) Maleinic acid anhydride and D-ribose from Theodor Schuchardt, München. c) Dowex I X -4, 200-400 mesh, Cl--Form, Dowex WX-50, $\mathrm{H}^{+}$-Form from Serva-Entwicklungslabor, Heidelberg.

All other reagents were of analytical grade.

2. Preparation of D-ribulose and D-xylulose was performed according to Toustor's method [3].

3. Experimental animals

The following experimental animals wore used:

I. Male guinea pigs weighing $250-300 \mathrm{~g}$ from Firma Gierlich, Bochum,

II. male Wistar II rats (Firma Brünger, Bokel, Westfalen) with an average weight of $200 \mathrm{~g}$.

Rats were made diabetic by intraperitoneal injection of alloxan [8].

The blood sugar concentration in the diabetic animals was analysed by the glucose-oxidase method. The glucose concontration in the urine was determined by test tape.

The animals were decapitated and heart, liver, kidney, spleen, muscle, brain and epididymal fat pad were excised as rapidly as possible, cooled immediately and then homogenized in $0.154 \mathrm{M} \mathrm{KCl}-0.04 \mathrm{M} \mathrm{NaHCO}, \mathrm{pH}=$ 7.2. The homogenization was performed at $0^{\circ} \mathrm{C}$ during $90 \mathrm{sec}$ with a homogenizer of Firma Bühler, Erlangen. The blender was driven at top speed for 90 sec. 'The tissue homogenate was spun down at $100000 \mathrm{~g}$ for $30 \mathrm{~min}$ at $0^{\circ} \mathrm{C}$. The clear supernatant was takon for the determination of enzyme activity and protein content, according to Lowry et al. [9].

The activity of the gluconokinase was measured according to Leder [10], of the sorbitol dehydrogenase according to Gerlach [11], of the D-ribulokinase and D. xylulokinase according to Hickrnan and Ashwoll [12].

\section{Results}

\section{Preparation of D-ribulose}

a) Preparation of D-ribulose by paper chromatography (Touster [3])

D-ribulose was prepared from D-ribose after isomerisation in pyridine. The separation of $D$-ribulose from D-ribose was performed by paper chromatogra- 
phy. The gain of D-ribulose was about $100 \mathrm{mg}$ per paper sheet. The D-ribulose was eluted and concentrated to a colourless syrup. In the orcin reaction the characteristic absorption spectrum was seen with a maximum at 435,540 and $670 \mathrm{~nm}$. The ratios of the maximum absorption were $\mathrm{E}_{435} / \mathrm{E}_{540}=0.58$ and $\mathrm{E}_{540} /$ $\mathrm{E}_{670}=0.68$. The purity of the isolated ribulose was tested by thin-layer chromatography on Kieselgel G. with the solvent system ethylacetic acid: isopropanol $65: 35$. The following $R_{1}$-values were found:

D-ribulose : 0.36 , D-ribose : 0.26 .

The preparation of $\mathrm{D}$-xylulose was performed similarly. Therevwas no D-ribose and $\mathrm{D}$-xylose in our preparation of D-ribulose and D-xylulose as tested by thin-layer chromatography.

b) Preparation of D-ribulose and D-xylulose by ion exchange chromatography (Khym and Zill [7])

With this method we could not get satisfactory results. Although the elution buffer was varied over a wide range we could not find any pure fraction with the typical spectrum of the ribulose, the maximum absorption at $540 \mathrm{~nm}$ being always lower than at 435 $\mathrm{nm}$. There were always impurities of D-ribose and D. xylose in our preparation as revealed by thin-layer chromatography. ble 1

b) Activity of the sorbitol dehydrogenase (Ta.

Activity of sorbitol dehydrogenase was found in all investigated tissues. Like gluconokinase, the highest activity was found in liver and kidney. The testis had only $1 / 10$ of this activity, followed by the spleen and the heart. In brain, muscle and adipose tissue there was only $0.5-3 \%$ of the activity found in liver and kidney.

c) Activity of the D-xylulokinase (Table 1)

The activity of this enzyme was found in all tested organs and was highest in the liver, when referred to wet weight. $25-30 \%$ of the activity in liver was found in kidney, muscle, adipose tissue, spleen and brain. In testis and heart there was only $15 \%$ of the liver activ. ity.

When the activity of the enzyme was referred to soluble protein, the highest activity was found in adipose tissue, which exceeded the activity in liver by $160 \%$ ( $1 \mathrm{~g}$ adipose tissue contained $1.5 \%$ protein).

d) Activity of the D-ribulokinase (Table 1)

The highest activity was found in the liver, when referred to wet weight. Lower activities were found in spleen, kidney, muscle, adipose tissue, heart and testis $(50-20 \%)$. The lowest enzyme activity, with $10 \%$ of

Table 1. Activity of D-gluconokinase, D-xylulokinase, D-ribulokinase and sorbitol dehydrogenase in the organs of guinea pigs $(n=6)$. Upper line: $n$ moles/g wet weight $\times$. min. Lower line: $n$ moles $/ m g$ protein $\times$ min

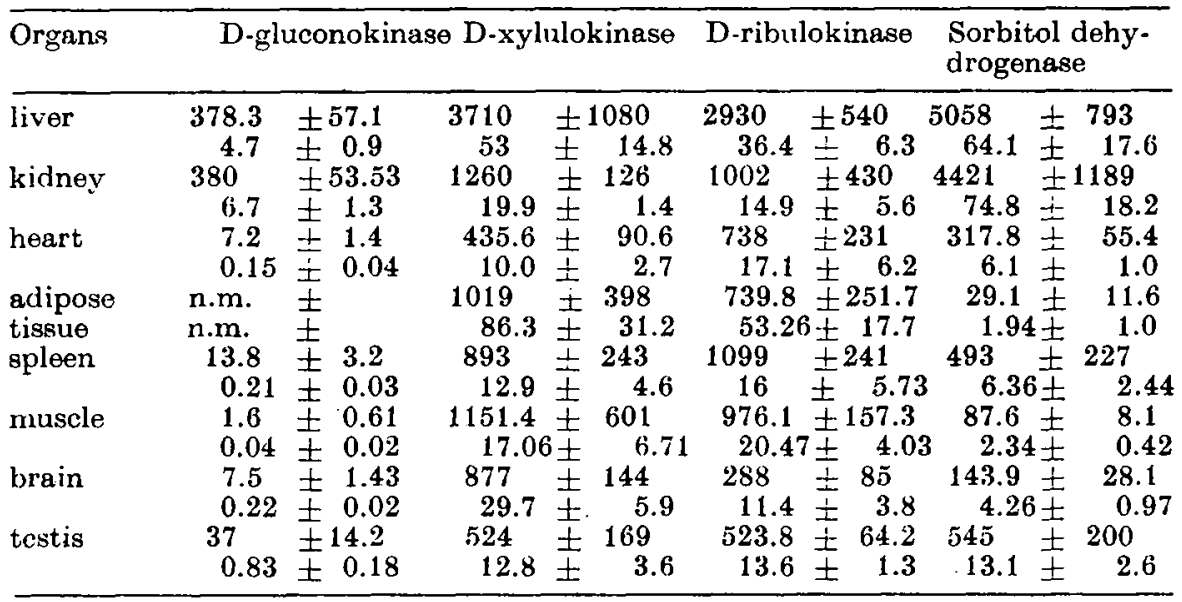

\section{Determination of enzyme activity in the organs of the guinea pig}

a) Activity of the gluconokinase (Table 1)

The activity of the gluconokinase was found in all tissues except adipose tissue, where the activity of the enzyme could not be determined. The highest activity was found in liver and kidney, when expressed in terms of wet weight as well as mg protein. The testis had only $10 \%$ of the activity compared with the liver. The other organs had only $0.5-4 \%$ of the activity found in liver. the activity in liver, was found in the brain. When the enzyme activity was referred to soluble cell protein, adipose tissue exceeded the activity in the other organs $(150 \%)$.
3. Comparison of the enzyme activities in the tested organs (Table 1)
Quantitative ratios of the single enzyme activities did not give constant proportions. The gluconokin- ase had the lowest activity of all ATP-transferases as seen in the 8 investigated organs, the activity being 
only $1 / 10$ of the D-xylulokinase and D-ribulokinase. The activities of ATP-transferases and sorbitol dehydrogenase have the same order of magnitude in the liver, kidncy, heart, spleen, and testis. In arlipose tissue the activity of the sorbitol dehydrogenase is only $3.5 \%$ of the D-xylulokinase and D-ribulokinase.

4. Activities of the gluconokinase and xylulokinase in normal and diabetic rats (Table 2)

The activities of the tested ATP-transferases are reduced by $50 \%$ in the organs of diabetic animals compared with the controls. The difference is statistically significant (for the xylulokinase $P<0.01$ and for the gluconokinase $P<0.005$ ).

Table 2. Activity of D-xylulokinase in the epididymal fat pad of the normal and diabetic rat

$n n$ moles/g wet weight $n$ moles/mg protein $\times \min$ $\times \min$

\begin{tabular}{|c|c|c|c|}
\hline $\begin{array}{l}\text { normal } \\
\text { rats } \\
\text { diabetic } \\
\text { rats }\end{array}$ & 7 & $\begin{array}{l}485 \pm 192 \\
243.2 \pm 59.1\end{array}$ & $\begin{array}{l}55 \quad \pm 18 \\
27.3+4.2\end{array}$ \\
\hline \multicolumn{4}{|c|}{$\begin{array}{c}\text { Activity of D-glaconolinase in the liver of normal and dia } \\
\text { betic rats }\end{array}$} \\
\hline $\begin{array}{l}\text { normal } \\
\text { rats } \\
\text { diabotic }\end{array}$ & 6 & $237.1=59.5$ & 2.4 之: 0.6 \\
\hline rats & 6 & $140.4 \pm 30.2$ & $1.4 \pm 0.2$ \\
\hline
\end{tabular}

\section{Discussion}

In recent years xylitol has attained some clinical application in diabetes therapy. The adult organism can degrade $10-20 \mathrm{mg}$ xylitol per minute per $\mathrm{kg}$ body weight. This degradation can be compared with the metabolism of fructose and corresponds to approximately $80 \%$ of the glucose metabolism. Xylitol can be metabolised without insulin and it was assumed that approximately $80 \%$ of the xylitol is degraded in the liver, the remaining $20 \%$ being metabolised in extrahepatic organs, namely in the kidney [25]. The erythrocytes [17], the heart muscle of the guinea pig [18] and the adipose tissue $[19,20]$ are able to metabolise xylitol, too. In adipose tissue xylitol has an antilipolytic action without raising the blood sugar concentration; the radioactivity of the applied xylitol- ${ }^{14} \mathrm{C}$ is found firstly as ${ }^{14} \mathrm{CO}_{2}$ or in lipids respectively [26]. As the metabolism of xylitol follows initial dehydrogenation with the aid of NAD-xylitol dehydrogenase (polyol dehydrogenase) via D-xylulose-5-phosphate, the activity of these enzymes was determined in several organs. Simultaneously the activities of the D-ribulokinase and D-gluconokinase were measured.

Surprisingly we found high enzyme activities of the pentulokinases in adipose and muscle tissues. The predominance of adipose tissue in the enzyme activities of the pentulokinases is scen when the enzyme activity is referred to soluble cell protein. For the metabolism of pentitols in adipose tissue free permeability of the polyalcohols across the cell membrane and dehydrogenation from pentitols to pentuloses must proceed. The permeation of the polyalcohols is not controlled by insulin [23]. The dehydrogenation of xylitol is performed by a NAD-xylitol dehydrogenase in adipose tissue [21]. The antiketogenic effect of xylitol in diabetes may be explained - apart from the effect of $x y$ litol on insulin secretion in the islets of pancreas by the metabolism in the liver and in adipose tissue, via xylulose-5-phosphate to $\mathrm{CO}_{2}$, acetyl-CoA and $\alpha$ glycerophosphate, respectively. These compounds are metabolites of the synthesis of fatty acids and triglycerides. The muscle tissue has high enzyme activities too. If these enzyme activities are referred to the whole muscle mass and the whole adipose tissue of the body, then the total activity in these tissues exceeds the activity of the liver and kidney. Therefore balances in the degradation of xylitol or ribitol must take into consideration the whole fat and muscle tissue of the organism.

'The rate-limiting step in the degradation of xylitol seems to be the NAD-xylitol-dehydrogenase, the activity of this enzyme being lower in the fat pad than the activity $\mathrm{D}$-xylulokinase (D-xylulokinase $55 \pm 18 \mathrm{nMol}$ ! $\mathrm{mg}$ protein/min, NAD-xylitol-dehydrogenase $15.2 \pm$ $3.4 \mathrm{nMol} / \mathrm{mg}$ protein $/ \mathrm{min}$ [21]). In diabetic rats the activity of the gluconic acid pathway should be enhanced [22]. In contrast we found the activity of the D-xylulokinase diminished. In this field further investigations must be carried out.

In contrast to the pentulokinases the other two tested enzymes, D-gluconokinase and sorbitol dehydrogenase, show another activity pattern in the tested organs. We found low, sometimes not determinable activity of the $\mathrm{D}$-gluconokinase in adipose and muscle tissue, so that the metabolism of D-gluconate seems only to be possible in liver, kidney, brain and heart muscle. In this case the liver and kidney must have a nutritive function for the adipose and muscle tissue.

\section{Literatur}

1. Hollmann, S.: Extraglycolytische Umsotzung. In: DGlucose und verwandto Verbindungen in Medizin und Biologie. Hrsg. von Bartelheimer, H., Heyde, W., 'Thorn, W., p. 340. Stuttgart: Fordinand Enke 1966. 2. Fromm, H.J.: D-Ribulokinase from aerobacter acro genes. J. biol. Chem. 234, 3097 (1959).

3. Touster, O.: D- and L-threo-pentulose (I)- and Lxyluloso). In: Methods in carbohydrate chenistry. Hrse. von Whistler, R.L., Wolfrom, M.L., Band I, p. 98. Now York and London: Academic Press, 1962.

4. Hollmann, S.: Nichtglycolytische Stoffwechselwege der Glucose. Stuttgart: Georg Thieme 1961.

5. Stahl, E.: Dünnschichtchromatographic. 2. Aufl, p. 794. Borlin-Heidolberg-Now York: Springer 1967.

6. Putman, E. W.: Methods in Enzymology. Hrsg. von Colowick, S.P., Kaplan, N.O., Band 3, p. 57. New York: Academic Press 1957.

(ja. Hochster, R.M.: The formation of phosphorylated sugars from $\mathrm{D}$-xylose by extracts of pseudomonas hydrophila. Can. J. Microbiol. 1, 346 (1955). 
7. Khym, J.X., Zill, L.P.: The separation of sugars by ion exchango. J. Amer. chem. Soc. 74, 2090 (1952).

8. Wioland, O., Löffler, G., Weiss, U., Neufeldt, J.: Zur Acetessigsäure- und Cholesterinbildung bei oxperimenteller Ketose. Biochem. Z. 333, 10 (1960).

9. Lowry, O.H., Rosebrough, N.J., Farr, A.I., Randall, R.J.: Protein measurement with the Folinphenolreagent. .J. biol. Chem. 193, 265 (1951).

10. Leder, J.G.: Hog kidney ghleonokinase. J. biol. Chom. 225, $12 \overline{0}$ (1957)

Ballard, F.J., Oliver, I. T.: The effect of concentration on glucose phosphorylation and incorporation into glycogen in tho livers of foetal and adult rats and shoep. Biochem. J. 92, 131 (1964).

11. Gerlach, U.: Sorbit-Dehydrogenase. In : Methoden der enzymatischen Analyse. Hrsg. von H.-U. Bergmeyer. Weinheim/Bergstraßc: Chemie GmbH 1962.

12. Hickman, J., Ashwell, G. : Purification and properties of D-xylulokinase in liver. J. biol. Chem. 232, 737 (1958).

13. Dische, Z., Borenfreund, E.: A new spoctrophotometric method for the detection and determination of keto sugars and trioses. J. biol. Chem. 192, 583 (1951).

14. Kameyama, ' $\Gamma$., Shimazono, N.: Enzymic phosphorylation of D-ribulose in guinea-pig liver. Biochim. biophys. Acta 64, 180 (1962).

15. Lang, K.: Utilisation of xylitol in animals and man. International symposion on metabolism, physiology and clinical use of pentoses and pentitols, Hakone, August 1967. Hrsg. von Horecker, B. L., Lang, K. Berlin-Heidelborg-New York: Springer 1969.

16. Bässler, K.H.: Adaptive processes concerned with absorption and metabolism of xylitol. International symposium on metabolism, physiology and clinical use of pontoses and pentitols, Hakone, August 1967. Hrsg. von Horecker, B.L., Lang, K. Berlin-Heidelberg-New York: Springer 1969.

17. Bässler, K.H., Reimold, W.V.: Lactatbildung aus Zuckern und Zuckeralkoholen in Erythrocyten. Klin. Wschr. 43, 169 (1965).

18. Bickel, $H$.: Exporimental findings on the utilization of xylitol in heart muscle of the guinea pig. International symposium on metabolism, physiology and clinical use of pentoses and pontitols, Hakone, August 1967. Hrsg. von Horeckor, B.L., Lang, K. Berlin-Hcidelborg-New York: Springer 1969.
19. Opitz, K.: The influence of xylitol and othor polyols and sugars in its effect on fat mobilisation. International symposium on metabolism, physiology and clinical use of pentoses and pentitols, Hakone, Auguast 1967. Hrsg. von Horecker, B.L., Lang, K. Berlin-Hëidelberg-New York: Springer 1969.

20. Yamagata, S., Goto, Y., Ohneda, A., Anzai, M., Kawashima, S., Chiba, M., Maruhama, Y., Yamauchi, T.: Clinical effects of xylitol on carbohydrate and lipid motabolism in diabetes. Lancet 1965 II, 918.

21. Petrich, Ch., Reinauer, H., Hollmann, S.: Vergleichonde Aktivitätsmessungen der Enzyme des Glucuronsäure-Xylulose-Cyclus in der. Leber, dem epididymalen Fettgewebe der Ratte. Z. klin. Chemie, 10, 355 (1972).

22. Winegrad, A.J.: The activity of the glucuronic acid pathway in human and experimental diabetes. International symposion on metabolism, physiology and clinical use of pentoses and pentitols, Hakone, August 1967. Hrsg. von Horecker, B. L., Lang, K. Berlin-Heidelberg-New York: Springer 1969.

23. Bässler, K.H., Prellwitz, W.: Insulin und der Verteilungsraum von Xylit in eviscerierten Ratton. Klin. Wschr. 42, 94 (1964).

24. Bässler, K.H., Prellwitz, W., Unbehaun, V., Lang, K.: Zur Frage der Eignung von Xylit als Zuckerersatz beim Diabetiker. Klin. Wschr. 40, 791 (1962).

25. Schmidt, B., Fingerhut, M., Lang, K. : Utber den Stoff. wechsel von radioaktiv markiertem Xylit bei der Rat. te. Klin. Wschr. 42, 1073 (1964).

26. Mehnert, H., Summa, J.D., Förster, H.: Untersu. chungen zum Xylitstoffwechsol bei gesunden, leber. kranken und diabetischen Personen. Klin. Wschr. 42, 383 (1964).

27. Wang, M.C., Meng, H.C.: Xylitol metabolism in extrahepatic tissues. Z. Ernährungswissenschaft, Suppl. 11, 8 (1971).

28. Hollmann, S., Reirauer, H.: Stoffwechsel der Pentosen und Pentitole. Z. Ernährungswissenschaft, Suppl. 11, 1 (1971).

Priv. Doz. Dr. H. Reinauer

Diabetes-Forschungsinstitut an der Universität

D-4000 Düsseldorf-Benrath

Hospitalstr. 1

Federal Republic of Germany 